\title{
Can the invasive ambrosia beetle Xylosandrus germanus withstand an unusually cold winter in the West Carpathian forest in Central Europe?
}

\author{
Marek Dzurenko ${ }^{1 *}$, Juraj Galko², Ján Kulfan ${ }^{3}$, Jozef Vál'ka ${ }^{3}$, Juraj Holec ${ }^{4}$, Miroslav Saniga ${ }^{3}$, \\ Milan Zúbrik ${ }^{2}$, Jozef Vakula ${ }^{2}$, Christopher M. Ranger ${ }^{5}$, Jiří Skuhrovec ${ }^{6}$, Terézia Jauschováa ${ }^{3,7}$, \\ Peter $\mathbf{Z a c h}^{3}$
}

${ }^{1}$ Department of Integrated Forest and Landscape Protection, Faculty of Forestry, Technical University in Zvolen, T. G. Masaryka 24, 96001 Zvolen, Slovakia

${ }^{2}$ Forest Research Institute Zvolen, National Forest Centre, T. G. Masaryka 22, 96092 Zvolen, Slovakia ${ }^{3}$ Institute of Forest Ecology, Slovak Academy of Sciences, L. Štúra 2, 96053 Zvolen, Slovakia ${ }^{4}$ Slovak Hydrometeorological Institute, Jeséniova 17, 83315 Bratislava, Slovakia

${ }^{5}$ Horticultural Insects Research Lab, Application Technology Research Unit, USDA Agricultural Research Service, 1680 Madison Ave., Wooster, OH 44691, USA

${ }^{6}$ Group Function of Invertebrate and Plant Biodiversity in Agro-Ecosystems, Crop Research Institute, Drnovská 507, CZ 16106 Praha 6 - Ruzyně, Czech Republic

${ }^{7}$ Faculty of Ecology and Environmental Sciences, Technical University in Zvolen, T. G. Masaryka 24, 96001 Zvolen, Slovakia

\begin{abstract}
Dzurenko, M., Galko, J., Kulfan, J., Váleka, J., Holec, J., Saniga, M., Zúbrik, M., Vakula, J., Ranger, C.M., Skuhrovec, J., Jauschoví, T., ZACH, P., 2022. Can the invasive ambrosia beetle Xylosandrus germanus withstand an unusually cold winter in the West Carpathian forest in Central Europe? Folia Oecologica, 49 (1): $1-8$.
\end{abstract}

\begin{abstract}
The capability of a non-native species to withstand adverse weather is indicative of its establishment in a novel area. An unusually cold winter of 2016/2017 that occurred in the West Carpathians of Slovakia and other regions within Europe provided an opportunity to indirectly assess survival of the invasive ambrosia beetle Xylosandrus germanus (Coleoptera: Curculionidae, Scolytinae). We compared trap captures of this species in the year preceding and succeeding the respective cold winter. Ethanol-baited traps were deployed in 24 oak dominated forest stands within the southern and central area from April to August 2016, and again from April to August 2017 to encompass the seasonal flight activity of $X$. germanus and to get acquainted with temporal changes in the abundance of this species in these two distant areas. Dispersing $X$. germanus were recorded in all surveyed stands before and after the aforementioned cold winter. Their total seasonal trap captures were lower in the southern area following low winter temperatures, but remained similar in the central area. Our results suggest that $X$. germanus can withstand adverse winter weather in oak dominated forests of the West Carpathians within altitudes of 171 and $450 \mathrm{~m}$ asl. It is likely that minimum winter temperatures will not reduce the establishment or further spread of this successful invader in forests in Central Europe.
\end{abstract}

Keywords

black timber bark beetle, invasive species, overwintering, Slovakia, Xyleborini

*Corresponding author:

e-mail: marek.dzurenko@gmail.com

sciendo

(C) 2022 Authors. This is an open access article under the CC BY-NC-ND license (http://creativecommons.org/licenses/by-nc-nd/4.0/) 


\section{Introduction}

The black timber bark beetle Xylosandrus germanus (Blandford) (Coleoptera, Curculionidae, Scolytinae) is an ambrosia beetle native to Eastern Asia (Iто et al., 2008) that has become a destructive alien pest in North America and Europe (RANGER et al., 2016; CABI, 2019; GALKo et al., 2019). In North America, $X$. germanus reportedly attacks living but weakened trees in ornamental nurseries (RANGER et al., 2016) and tree fruit orchards (AGNELLO et al., 2015, 2017). Within Europe, this species has been documented attacking living but weakened trees (LA SPINA et al., 2013) and recently felled logs (GALKo et al., 2019; HAUPTMAN et al., 2019). Its present spread in Central Europe is facilitated by timber trade and climate change (OLENICI et al., 2014; GaLKo et al., 2019; Fiala et al., 2020).

Xylosandrus germanus is univoltine in Central Europe (GALKo et al., 2014; 2019) and overwinters as an adult in host trees, presumably clustered within host galleries (Weber and McPherson, 1983). The flight activity of this species in the West Carpathians in Slovakia begins in April, peaks in mid-June, and ends in August (GALKo et al., 2014). After emerging in spring from their overwintering galleries, dispersing adults show a strong attraction to ethanol (KLimetZeK et al., 1986; RANGer et al., 2010; REDING et al., 2010) which is emitted from recently felled logs (KELSEY, 1994) and physiologically-stressed trees (RANGER et al., 2013; 2019). Ethanol-baited traps are effective for monitoring of the seasonal flight activity of this ambrosia beetle (Oliver and MANnion, 2001; Reding et al., 2013; AGNELlo et al., 2017).

The distribution and abundance of bark and ambrosia beetles in novel habitats is limited by various factors, including habitat heterogeneity, availability of host resources, climate, and antagonists (PARK and REID, 2007; Brin et al., 2011; BussLer et al., 2011; MARINI et al., 2011; Watanabe et al., 2014; Rassati et al., 2016; Gossner et al., 2019). In particular, minimum winter temperatures are considered an important factor influencing the reproduction, development, and flight synchronization of scolytines following their introduction to novel habitats (UNGERER et al., 1999; SAuvard, 2007; Brar et al., 2015; Formby et al., 2018). For instance, BrAR et al. (2015) measured the temperature-dependent development of the redbay ambrosia beetle, Xyleborus glabratus (Eichhoff), and predicted that minimum winter temperatures will limit the northern range of this exotic species. FormBY et al. (2018) provided additional evidence that $X$. glabratus is a freeze intolerant and chill susceptible species. Similarly, minimum winter temperature has been proposed as a key parameter that could limit the survival, establishment, and distribution of $X$. germanus (HolzschuH, 1993; Bruge, 1995; Henin and Versteirt, 2004; HAUPTMAN et al., 2019), but the cold tolerance of this species has not been characterized. BRUGE (1995) proposed that temperature regime explains why $X$. germanus is univoltine in Europe and bivoltine in North America.
In January 2017, unusually cold winter temperatures occurred in Central, Southeastern and Eastern Europe (ANAgnostopoulou et al., 2017; TURŇA et al., 2017). In Slovakia, Central Europe, the winter of 2016/2017 was reported to be the $30^{\text {th }}$ coldest winter since 1901 and the coldest winter since 2006. In most parts of this country, January 2017 was the coldest January since 1985 (TURŇA et al., 2017). Similar characteristics for this winter were reported from Slovenia where January 2017 was the coldest January over the last three decades (HAUPTMAN et al., 2019). This climatic event provided an opportunity to indirectly assess whether $X$. germanus can withstand these cold temperatures.

To gain more insights into the capability of $X$. germanus to withstand cold winter temperatures in the forested stands in the West Carpathians of Slovakia, where this species was first recorded in 2010 (GALKO, 2013), our current study compared the captures of this species in ethanol-baited traps deployed within southern vs. central forests in the West Carpathians in the year preceding and succeeding the respective cold winter of 2016/2017.

Xylosandrus germanus has been established in Western Europe since at least 1951 (WichmanN, 1955; KAMP, 1968). We hypothesized, in the given context, this species could withstand instances of unusually cold winter temperatures in Central Europe.

\section{Materials and methods}

\section{Research area}

Our study was carried out in oak (Quercus spp.) dominated forest stands in the southern and central area of the West Carpathians in Slovakia, Central Europe. The two areas are approximately $60 \mathrm{~km}$ from each other. The southern area is situated in Krupinská planina Plateau (locations Medovarce, Plášt'ovce, Dudince) within altitudes between 171 and $304 \mathrm{~m}$ asl, and is characterized by warm and dry climate; the central area lies in Pliešovská kotlina basin (location Breziny) and Kremnické vrchy Mountains (locations Vel'ká Stráž, Budča, Kováčová, Železná Breznica) between 259 and $450 \mathrm{~m}$ asl, and is characterized by moderately warm and moderately humid climate (ŠŤASTNÝ et al., 2015). Temperature measurements (19612010 ) in the month of January range between -2 to $-1{ }^{\circ} \mathrm{C}$ in the southern area, and -3 to $-2{ }^{\circ} \mathrm{C}$ in the central area (ŠŤASTNÝ et al., 2015).

Daily air temperatures during the exceptionally cold winter of 2016/2017 were provided by the meteorological stations of the Slovak Hydrometeorological Institute (SHMÚ) at the location Dudince for the southern area (Fig. 1A) and at the location Sliač for the central area (Fig. 1B).

To gain broader climatological insights about an unusually cold January 2017, the temperature averages for January 1991-2020 and January 2001-2020 were compiled using the data from these meteorological stations. 

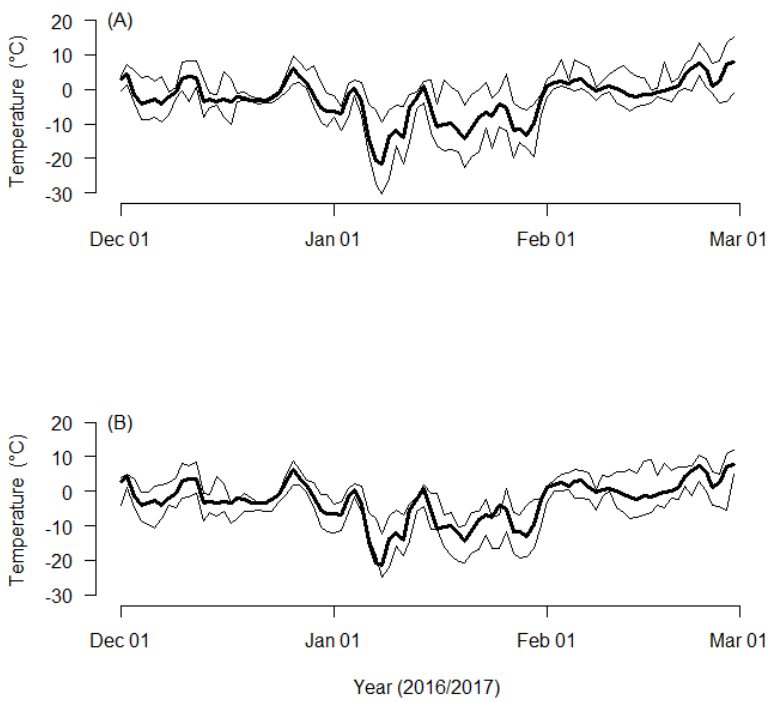

Fig. 1. Daily air temperatures during the winter of 2016/2017 (December-February) for the southern (A) and the central area of the West Carpathians (B). Thin lines: minimum and maximum temperatures, thick line: average temperatures. Source data: southern area - Meteorological Station Dudince, central area - Meteorological Station Sliač (Slovak Hydrometeorological Institute 2019).

\section{Trapping protocol}

Twelve locations were selected for deploying traps within both the southern and central forested areas. One trap was then deployed per oak stand $(\mathrm{n}=12)$ in the southern area and one trap per stand $(\mathrm{n}=12)$ in the central area to capture $X$. germanus during their seasonal flight activity in 2016 and 2017. The position of traps in forested stands was the same in 2016 and 2017. During the first year of the study, traps were deployed from 15 April 2016-26 August 2016 in the southern area, and 25 April 2016-23 August 2016 in the central area. In the second year of the study, traps were deployed from 22 April 2017-24 August 2017 in the southern area, and 25 April 2017-22 August 2017 in the central area. Trapping in each forested stand started before $X$. germanus emerged from overwintering sites within host substrates and terminated when few or no $X$. germanus were captured.

The traps were $1.5 \mathrm{~L}$ plastic bottles with a cutout window $(10 \times 20 \mathrm{~cm})($ Steininger et al., 2015). The bottles were inverted with the collecting solution (an aqueous $\mathrm{NaCl}$ ) contained within the bottle neck. Each trap was baited with aqueous solutions of $85 \%$ absolute ethanol (Galvex, LLC) contained in a $100 \mathrm{ml}$ plastic bottle with four circular openings (diameter $2.5 \mathrm{~mm}$ ) spaced regularly along the upper circumference of the bottle. Each plastic bottle contained an equal amount $(75 \mathrm{ml})$ of ethanol. The release rate of ethanol was measured as $0.73 \pm 0.09 \mathrm{~g}$ per day $(\mathrm{n}=10)$ at $19^{\circ} \mathrm{C}$. The traps were attached to the lower branches of oak trees at 1.5-1.8 $\mathrm{m}$ above the ground with the cutout window of each trap facing the south-east. A minimum distance of approximately $100 \mathrm{~m}$ was maintained between the nearest traps to ensure independence of captures. All traps were inspected, ethanol replenished, and captured beetles collected approximately every two weeks. Captured beetles were stored in $40 \%$ ethanol, identified, and counted in the laboratory.

\section{Statistical analysis}

The average and minimum daily temperatures in January 2017 (data from meteorological stations at Dudince and Sliač) were compared between the southern area and the central area using a paired two-sample t-test. The ShapiroWilk normality test was used to test the temperature data for the normality, and the F-test for homogeneity of variances was applied to find whether the variances of the two temperature data sets had equal (similar) variance.

The total captures of $X$. germanus over the trapping period preceding and succeeding the cold winter of 2016/2017 were compared to assess temporal change in the beetle population. Due to violation of the independence assumption (sequential captures of the beetle within the same forested stands), Generalised Estimating Equations, GEE (LiANG and ZEGER, 1986), were used to analyse the data. The response variable was the number of $X$. germanus captured in oak stands in the southern $(n=12)$ and the central area of the West Carpathians $(n=12)$ over the entire trapping period. The categorical explanatory variable consisted of two levels ("2016" and "2017") referring to particular years before and after the respective cold winter. The grouping structure in the data was designated by the identity of the particular block identification within the forested stands.

Computations were performed in $\mathrm{R}$ ( $\mathrm{R}$ CORE TEAM, 2019). GEE were applied using the geepack package within R (HALEKOH et al., 2006).

\section{Results}

The variation in temperatures in the southern and the central area of the West Carpathians during the winter of 2016/2017 showed similar temporal patterns (Fig. 1A, B). The average daily temperatures in January 2017 did not significantly differ between the southern $\left(-8.9 \pm 5.4^{\circ} \mathrm{C}\right)$ and the central area $\left(-9.7 \pm 4.9^{\circ} \mathrm{C}\right)(\mathrm{t}=1.895, \mathrm{df}=30, \mathrm{p}$ $=0.068$ ). The minimum daily temperatures over the same time period were also not significantly different between the southern area $\left(-15.3 \pm 6.8^{\circ} \mathrm{C}\right)$ and the central area $\left(-14.5 \pm 5.5^{\circ} \mathrm{C}\right)(\mathrm{t}=-1.535, \mathrm{df}=30, \mathrm{p}=0.135)$. The range of minimum temperatures in January 2017 was wider in the southern area $\left(-30.3\right.$ to $\left.-1.9{ }^{\circ} \mathrm{C}\right)$ than the central area $\left(-24.9\right.$ to $\left.-1.8{ }^{\circ} \mathrm{C}\right)$, indicating greater extremeness of winter temperatures in the southern area. Minimum daily temperatures in January 2017 compared with the average temperatures in January 2017, January 1991-2020 and January 2001-2020 provide broader insights about extremeness of the cold January 2017 in the southern area (Fig. 2A) and the central area (Fig. 2B). 


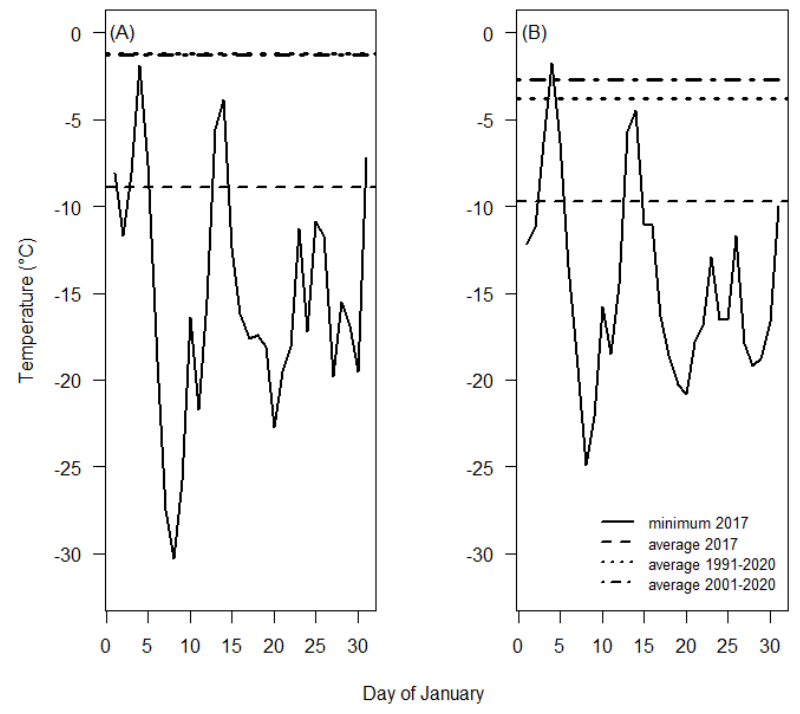

Fig. 2. Minimum daily temperatures in January 2017 (solid line) compared to the average temperature in January 2017 and the long-term temperature averages in January (1991-2020, 2001-2020) for the southern (A) and the central area of the West Carpathians (B). The long-term temperature averages for the southern area are overlapping. Source data: southern area - Meteorological Station Dudince, central area - Meteorological Station Sliač (Slovak Hydrometeorological Institute 2019).

Judged from the meteorological data, snow cover during the winter persisted for 44 days in the central area and 36 days in the southern area, and it was 1-22 mm thick in the central area and 1-17 mm thick in the southern area.

A total of 23,855X. germanus specimens were captured. Specifically, a total of 1,620 specimens were collected from the southern area in 2016 and 2017 combined compared to 22,235 specimens from the central area. Before and after the cold winter of 2016/2017, X. germanus was recorded in all surveyed oak stands.

In the southern area, significantly lower captures of $X$. germanus were recorded after the cold winter of 2016/2017 (GEE, Wald $=7.64, p=0.0057$ ) (Fig. 3A). A total mean of 99.9 beetles per trap ( $95 \%$ CIs: $32.4,307.7$ ) were captured in 2016 before the cold minimum temperatures compared to 35.1 beetles per trap (95\% CIs: $14.3,85.8)$ captured in 2017. The sequential observations on the number of $X$. germanus in the stands were correlated ( $\mathrm{cor}=0.58$, number of clusters $=12$, cluster size $=2$ ). A positive correlation (residuals) indicates dependence between the repeated captures of $X$. germanus from the same forested stands captures in these stands after the cold temperatures were proportional in size to captures in these stands before the cold temperatures (Fig. 3).

In the central area, the total captures of $X$. germanus in 2016 were not significantly different from trapping conducted in 2017 (GEE, Wald $=0, p=1.0$ ) (Fig. 3B). The total mean number of captured beetles per trap before the cold winter was 926 specimens (95\% CIs: 523, 1,640) compared to 927 specimens (95\% CIs: 604, 1,424) captured after the cold winter. There was a lower correlation between the sequential observations on the number of $X$. germanus in the forested stands (cor $=0.41$, number of clusters $=12$, cluster size $=2$ ) than in the southern area.
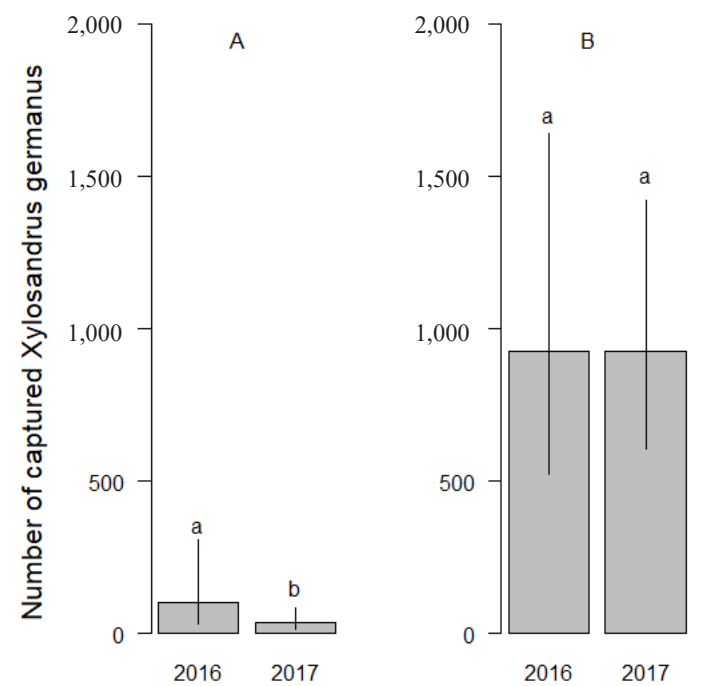

\section{Year of sampling}

Fig. 3. Mean number of captured Xylosandrus germanus in oak dominated stands over April-August 2016 and AprilAugust 2017 in the southern (A) and the central area of the Western Carpathians (B). In total, 12 stands were surveyed in each area every year. Bars denote the means, vertical lines the $95 \%$ confidence intervals $(\mathrm{CI})$ for the means. Differences at the 0.05 significance level are indicated by different letters above the CIs. Low winter temperatures occurred in January 2017.

\section{Discussion}

Due to climate change and rising air temperatures within Europe, cold winters are becoming infrequent and even rare (Murphy, 2000; JACOB et al., 2014). Despite this, extremely cold winters and their effects on wood boring insects should not be overlooked (BOGGS, 2016; FORREST, 2016; LeHMANn et al., 2020). The absence of records of $X$. germanus in the West Carpathians until 2000 was attributed to the comparatively extreme continental climate, specifically, low winter temperatures ( $\mathrm{ZACH}$ et al., 2001).

After the winter of 2016/2017, we recorded $X$. germanus in all surveyed oak stands, supporting our hypothesis that this species could withstand unusually low minimum winter temperatures in the forested stands in the West Carpathians at an elevation of 171-450 m. Results from our trapping study suggest stable populations of $X$. germanus in the moderately warm, moderately humid central area, based on the lack of difference in trap captures in 2016 vs. 2017. In the comparatively warm, dry southern area a significant reduction in trap captures occurred in 
most forested stands after the cold winter. Although we did not find the southern and northern area to be significantly different with regard to minimum and average daily temperatures during January 2007, the southern area consisted of a lower minimum temperature in January of $-30.3{ }^{\circ} \mathrm{C}$ (average $-15.3{ }^{\circ} \mathrm{C}$ ) compared to a minimum temperature of $-24.9^{\circ} \mathrm{C}$ (average $-4.5^{\circ} \mathrm{C}$ ) in the central area. This may provide indirect support to the statement that minimum winter temperature is a key parameter in limiting X. germanus (HolzschuH, 1993; BRUGe, 1995; Henin and Versteirt, 2004). In Slovenia, Hauptman et al. (2019), comparing the captures of $X$. germanus before and after the cold winter of $2016 / 2017$, suggested that minimum winter temperatures were not a limiting factor for $X$. germanus in lowlands but they would likely limit the establishment of $X$. germanus at higher altitudes.

Wood boring insects in breeding substrates are exposed to less extreme temperature than measured ambient temperature (MAYr et al., 2006; VERMUNT et al., 2012), which can also contribute to the overwintering success of species such as $X$. germanus. Overwintering success of xylophilous insects may also be affected by the thickness of snow cover. Low snow cover results in increased exposure of overwintering insects to cold temperatures, increasing their mortality (BALE and HaYward, 2010). During the winter of 2016/2017 snow cover was low in both areas and it probably did not provide significant protection of $X$. germanus from cold temperatures.

To our knowledge, the cold tolerance of $X$. germanus has not been described in the literature. Several works investigated cold tolerance in related invasive xyleborines Xyleborus glabratus (FormBy et al., 2013; 2018) and Euwallacea fornicatus species complex (COOPERBAND et al., 2016). The lower lethal temperature and supercooling point for $X$. glabratus were calculated as $-10{ }^{\circ} \mathrm{C}$ and -22 ${ }^{\circ} \mathrm{C}$, respectively, indicating that the beetle is a freezeintolerant and chill-susceptible species (FormBy et al., 2013 ; 2018). In the case of E. fornicatus, after being exposed to $-5^{\circ} \mathrm{C}, 100 \%$ of larvae, $95.7 \%$ of pupae and $69.2 \%$ of adults died. Of the surviving adults, many were on their backs, moving their legs only slightly after a 24-h recovery period, and exposure to $-1{ }^{\circ} \mathrm{C}$ caused similarly high levels of mortality in this species (COOPERBAND et al., 2016). Since $X$. germanus has a more northerly distribution than either $X$. glabratus or E. fornicatus, extending into Canada in North America (Gomez et al., 2018; RABAGLiA et al., 2019) and Scandinavia in Europe (BJöRKLUND and BOBERG, 2017), we expect its lower lethal temperature to be lower than those recorded for $X$. glabratus or $E$. fornicatus. Our results indicate that $X$. germanus is capable of withstanding freezing ambient temperatures below $-10{ }^{\circ} \mathrm{C}$, but additional studies are warranted.

\section{Conclusions}

Based on the results of this study, it is likely that extreme climatic events in the form of minimum winter temperatures will not reduce the establishment or further spread of $X$. germanus in forests in Central Europe within altitudes of 171 and $450 \mathrm{~m}$ asl. As observational longitudinal studies and, specifically, short-term observational longitudinal studies are less powerful to detect causal relationships than experiments (VAN DER KRIEKE et al., 2017), we recommend to conduct long-term observations on the number of $X$. germanus combined with field and laboratory experiments (e.g. estimating low lethal temperatures and supercooling point) to determine ultimate causes (e.g. temperature, snow cover, breeding substrates, etc.) of temporal changes in the population of $X$. germanus during its development.

\section{Acknowledgements}

The study was supported by the grants VEGA 2/0032/19, APVV 14-0567, APVV 16-0088 and APVV-19-0116, and J.S. was supported by the program VES19 INTER-COST No. MSMT-15739/2019-6 (MŠMT ČR) and the Ministry of Agriculture of the Czech Republic, institutional support MZE-RO0418. We thank Milan Mikuš (Institute of Forest Ecology, Slovak Academy of Sciences) for technical assistance during field studies.

\section{References}

Agnello, A., Breth, D., Tee, E., Cox, K., Warren, H.R., 2015. Ambrosia beetle-an emergent apple pest. New York Fruit Quarterly, 23: 25-28. [cit. 2021-05-04]. http:// nyshs.org/wp-content/uploads/2015/03/25-28-AgnelloPages-NYFQ-Book-Spring-2015.eg-5.pdf

Agnello, A.M., Breth, D.I., Tee, E.M., Cox, K.D., Villani, S.M., Ayer, K.M., Wallis, A.E., Donahue, D.J., Combs, D.B., Davis, A.E., Neal, J.A., 2017. Xylosandrus germanus (Coleoptera: Curculionidae: Scolytinae) occurrence, fungal associations, and management trials in New York apple orchards. Journal of Economic Entomology, 110: 2149-2164. https://doi.org/10.1093/ jee/tox 189

Anagnostopoulou, C., Tolika, K., Lazoglou, G., MAHERAS, P., 2017. The exceptionally cold January of 2017 over the Balkan Peninsula: A climatological and synoptic analysis. Atmosphere, 8 (12): 252. https://doi. org/10.3390/atmos 8120252

BaLe, J.S., HaYward, S.A.L., 2010. Insect overwintering in a changing climate. Journal of Experimental Biology, 213 (6): 980-994. https://doi.org/10.1242/jeb.037911

BJÖRKLUND, N., BOBERG, J., 2017. Rapid pest risk analysis Xylosandrus germanus. Unit for Risk Assessment of Plant Pests, Swedish University of Agricultural Sciences. [cit. 2021-04-08]. https://pub.epsilon.slu.se/15119/1/ xylosandrus-germanus-rapid-pest-risk-analysis.pdf

BogGs, C.L., 2016. The fingerprints of global climate change on insect populations. Current Opinion in Insect Science, 17: 69-73. https://doi.org/10.1016/j. cois.2016.07.004

Brar, G.S., Capinera, J.L., Kendra, P.E., Smith, J.A., PeÑA, J.E., 2015. Temperature-dependent development of Xyleborus glabratus (Coleoptera: Curculionidae: 
Scolytinae). Florida Entomologist, 98 (3): 856-864. https://doi.org/10.1653/024.098.0307

Brin, A., Bouget, C., Brustel, H., Jactel, H., 2011. Diameter of downed woody debris does matter for saproxylic beetle assemblages in temperate oak and pine forests. Journal of Insect Conservation, 15 (5): 653-669. https://doi.org/10.1007/s10841-010-9364-5

Bruge, H., 1995. Xylosandrus germanus (Blandford, 1894) (Belg. sp. nov.) (Coleoptera Scolytidae). Bulletin \& Annales de la Société Royale Belge d'Entomologie, 131 (2): 249-264.

Bussler, H., Bouget, C., Brustel, H., Brändle, M., Riedinger, V., Brandl, R., Müller, J., 2011. Abundance and pest classification of scolytid species (Coleoptera: Curculionidae, Scolytinae) follow different patterns. Forest Ecology and Management, 262 (9): 1887-1894. https://doi.org/10.1016/j.foreco.2011.08.011

CABI, 2019. Xylosandrus germanus (black timber bark beetle). [cit. 2020-6-15]. https://www.cabi.org/isc/ datasheet $/ 57237$

Cooperband, M.F., Stouthamer, R., Carrillo, D., Eskalen, A., Thibault, T., Cossé, A.A., Castrillo, L.A., Vandenberg, J.D., Rugman-Jones, P.F., 2016. Biology of two members of the Euwallacea fornicatus species complex (Coleoptera: Curculionidae: Scolytinae), recently invasive in the USA, reared on an ambrosia beetle artificial diet. Agricultural and Forest Entomology, 18 (3): 223-237. DOI: 10.1111/afe.12155

Fiala, T., Holuša, J., ProcházKa, J., Č́́žzk, L., Dzurenko, M., Foit, J., Galko, J., Kašák, J., Kulfan, J., Lakatos, F., Nakládal, O., Schlaghamerský, J., Svatoš, M., Trombik, J., ZÁbranskŕ, P., ZaCh, P., Kula, E., 2020. Xylosandrus germanus in Central Europe: spread into and within the Czech Republic. Journal of Applied Entomology, 144 (6): 423-443. https://doi.org/10.1111/ jen. 12759

Formby, J.P., Krishnan, N., Riggins, J.J., 2013. Supercooling in the redbay ambrosia beetle (Coleoptera: Curculionidae). Florida Entomologist, 96 (4): 15301541. https://doi.org/10.1653/024.096.0435

Formby, J.P., Rodgers, J.C., Koch, F.H., Krishnan, N., DuerR, D.A., Riggins, J.J., 2018. Cold tolerance and invasive potential of the redbay ambrosia beetle (Xyleborus glabratus) in the eastern United States. Biological Invasions, 20 (4): 995-1007. https:// doi.org/10.1007/s10530-017-1606-y

Forrest, J.R., 2016. Complex responses of insect phenology to climate change. Current Opinion in Insect Science, 17: 49-54. https://doi.org/10.1016/j.cois.2016.07.002

Galko, J., 2013. First record of the ambrosia beetle, Xylosandrus germanus (Blandford, 1894) (Coleoptera: Curculionidae, Scolytinae) in Slovakia. Forestry Journal, 58 (4): 279. [cit. 2021-05-21]. http://www.los.sk/ apvv/galko_biocom4_13.pdf

Galko, J., Dzurenko, M., Ranger, C.M., Kulfan, J., Kula, E., Nikolov, C., ZÚBRIK, M., ZACH, P., 2019. Distribution, habitat preference, and management of the invasive ambrosia beetle Xylosandrus germanus (Coleoptera: Curculionidae, Scolytinae) in European forests with an emphasis on the West Carpathians. Forests, 10 (1): 10. https://doi.org/10.3390/f10010010
Galko, J., Nikolov, C., Kimoto, T., Kunca, A., GubKa, A., VAKULA, J., ZÚBrIK, M., OstriHOŇ, M., 2014. Attraction of ambrosia beetles to ethanol baited traps in a Slovakian oak forest. Biologia, 69 (10): 1376-1383. https://doi. org/10.2478/s11756-014-0443-Z

Gomez, D.F., Rabaglia, R.J., Fairbanks, K.E., Hulcr, J., 2018. North American Xyleborini north of Mexico: a review and key to genera and species (Coleoptera, Curculionidae, Scolytinae). ZooKeys, 768: 19-68. https:// doi.org/10.3897/zookeys.768.24697

Gossner, M.M., Falck, K., Weisser, W.W., 2019. Effects of management on ambrosia beetles and their antagonists in European beech forests. Forest Ecology and Management, 437: 126-133. https://doi.org/10.1016/j. foreco.2019.01.034

Halekoh, U., Højsgaard, S., Yan, J., 2006. The R package geepack for generalized estimating equations. Journal of Statistical Software, 15 (2): 1-11. DOI: 10.18637/jss. v015.i02

Hauptman, T., Pavlin, R., Grošelu, P., Jurc, M., 2019. Distribution and abundance of the alien Xylosandrus germanus and other ambrosia beetles (Coleoptera: Curculionidae, Scolytinae) in different forest stands in central Slovenia. iForest, 12: 451-458. https://doi. org/10.3832/ifor3114-012

Henin, J.M., Versteirt, V., 2004. Abundance and distribution of Xylosandrus germanus (Blandford 1894) (Coleoptera, Scolytidae) in Belgium: new observations and an attempt to outline its range. Journal of Pest Science, 77 (1): 5763. https://doi.org/10.1007/s10340-003-0030-5

Holzschun, C., 1993. Erster Nachweis des Schwarzen Nutzholzborkenkäfers (Xylosandrus germanus) in Österreich [The first record of the black timber bark beetle Xylosandrus germanus in Austria]. Forstschutz Aktuell, 12 (10).

Ito, M., Kajimura, H., Hamaguchi, K., Araya, K., Lakatos, F., 2008. Genetic structure of Japanese populations of an ambrosia beetle, Xylosandrus germanus (Curculionidae: Scolytinae). Entomological Science, 11: 375-383. DOI: 10.1111/j.1479-8298.2008.00280.x

Jacob, D., Petersen, J., Eggert, B., Alias, A., Christensen, O.B., Bouwer, L.M., Braun, A., Colette, A., Déqué, M., Georgievski, G., Georgopoulou, E., 2014. EURO-CORDEX: new high-resolution climate change projections for European impact research. Regional Environmental Change, 14: 563-578. DOI: 10.1007/ s10113-013-0499-2

Kamp, H.J., 1968. Der „Schwarze Nutzholzborkenkäfer” Xylosandrus germanus Blandf., ein Neuling der heimischen Insektenfauna [The „,black timber bark beetle“ Xylosandrus germanus Blandf., a newcomer to the local insect fauna]. Entomologische Blätter, 64: 31-39.

Kelsey, R.G., 1994. Ethanol synthesis in Douglas-fir logs felled in November, January, and March and its relationship to ambrosia beetle attack. Canadian Journal of Forest Research, 24 (10): 2096-2104. DOI: 10.1139/ x $94-269$

KlimetzeK, D., KöHler, J., Vité, J.P., Kohnle, U., 1986. Dosage response to ethanol mediates host selection by "secondary" bark beetles. Naturwissenschaften, 73: 270272. DOI: 10.1007/BF00367783

La Spina, S., De Cannière, C., Dekri, A., Grégoire, J., 2013. Frost increases beech susceptibility to Scolytine 
ambrosia beetles. Agricultural and Forest Entomology, 15: 157-167. DOI: 10.1111/j.1461-9563.2012.00596.x

Lehmann, P., Ammunet, T., Barton, M., Battisti, A., Eigenbrode, S.D., Jepsen, J.U., Kalinkat, G., Neuvonen, S., Niemelä, P., Terblanche, J.S., OKland, B., Bü̈rkman, C., 2020. Complex responses of global insect pests to climate warming. Frontiers in Ecology and the Environment, 18 (3): 141-150. https://doi org/10.1002/fee. 2160

Liang, K., Zeger, S., 1986. Longitudinal data analysis using generalized linear models. Biometrika, 73: 13-22. https:// doi.org/10.1093/biomet/73.1.13

Marini, L., HaAck, R.A., Rabaglia, R.J., Toffolo, E.P., Battisti, A., FACCOli, M., 2011. Exploring associations between international trade and environmental factors with establishment patterns of exotic Scolytinae. Biological Invasions, 13 (10): 2275-2288. DOI: 10.1007/s10530011-0039-2

Mayr, S., Wieser, G., BAUer, H., 2006. Xylem temperatures during winter in conifers at the alpine timberline. Agricultural and Forest Meteorology, 137 (12): 81-88. DOI: 10.1016/j.agrformet.2006.02.013

MurPhy, J., 2000. Predictions of climate change over Europe using statistical and dynamical downscaling techniques. International Journal of Climatology, 20: 489-501. DOI: 10.1002/(SICI)1097-0088(200004)20:5<489::AIDJOC484>3.0.CO;2-6

Olenici, N., KnížeK, M., Olenici, V., Duduman, M.L., BIRIŞ, I.A., 2014. First report of three scolytid species (Coleoptera: Curculionidae, Scolytinae) in Romania. Annals of Forest Research, 57 (1): 87-95. DOI: 10.15287/afr.2014.196

Oliver, J.B., Mannion, C.M., 2001. Ambrosia beetle (Coleoptera: Scolytidae) species attacking chestnut and captured in ethanol-baited traps in middle Tennessee. Environmental Entomology, 30 (5): 909-918. https://doi. org/10.1603/0046-225X-30.5.909

PARK, J., ReID, M.L., 2007. Distribution of a bark beetle, Trypodendron lineatum, in a harvested landscape. Forest Ecology and Management, 242 (2-3): 236-242. https:// doi.org/10.1016/j.foreco.2007.01.042

R Core Team, 2019. R: A language and environment for statistical computing. Vienna: R Foundation for statistical computing. [cit. 2021-03-19]. https://www.R-project.org/

Rabaglia, R.J., Cognato, A.I., Hoebeke, E.R., Johnson, C.W., LaBonte, J.R., Carter, M.E., Vlach, J.J., 2019. Early detection and rapid response: a 10-year summary of the USDA forest service program of surveillance for non-native bark and ambrosia beetles. American Entomologist, 65: 29-42. https://doi.org/10.1093/ae/ tmz015

Ranger, C.M., Reding, M.E., Persad, A.B., Herms, D.A., 2010. Ability of stress-related volatiles to attract and induce attacks by Xylosandrus germanus and other ambrosia beetles (Coleoptera: Curculionidae, Scolytinae). Agricultural and Forest Entomology, 12: 177-185. DOI: 10.1111/j.1461-9563.2009.00469.x

Ranger, C.M., Reding, M.E., Schultz, P., Oliver, J., 2013. Influence of flood-stress on ambrosia beetle (Coleoptera: Curculionidae, Scolytinae) host-selection and implications for their management in a changing climate. Agricultural and Forest Entomology, 15: 56-64. https://doi.org/10.1111/j.1461-9563.2012.00591.x

Ranger, C.M., Reding, M.E., Schultz, P.B., Oliver, J.B., Frank, S.D., Addesso, K.M., Chong, J.H., Sampson, B., Werle, C., Gill, S., Krause, C., 2016. Biology, ecology, and management of nonnative ambrosia beetles (Coleoptera: Curculionidae: Scolytinae) in ornamental plant nurseries. Journal of Integrated Pest Management, 7: 1-23. https://doi.org/10.1093/jipm/pmw005

Ranger, C.M., Schultz, P.B., Frank, S.D., Reding, M.E., 2019. Freeze stress of deciduous trees induces attacks by opportunistic ambrosia beetles. Agricultural and Forest Entomology, 21: 168-179. https://doil.org/10.1111/ afe. 12317

Rassati, D., Faccoli, M., Battisti, A., Marini, L., 2016. Habitat and climatic preferences drive invasions of non-native ambrosia beetles in deciduous temperate forests. Biological Invasions, 18 (10): 2809-2821. https:// doi.org/10.1007/s10530-016-1172-8

Reding, M., Oliver, J., Schultz, P., Ranger, C.M., 2010. Monitoring flight activity of ambrosia beetles in ornamental nurseries with ethanol-baited traps: Influence of trap height on captures. Journal of Environmental Horticulture, 28 (2): 85-90. https://doi. org/10.24266/0738-2898-28.2.85

Reding, M.E., Ranger, C.M., Oliver, J.B., Schultz, P.B., 2013. Monitoring attack and flight activity of Xylosandrus spp. (Coleoptera: Curculionidae: Scolytinae): The influence of temperature on activity. Journal of Economic Entomology, 106 (4): 1780-1787. https://doi.org/10.1603/ EC13134

SAuvard, D., 2007. General biology of bark beetles. In Lieutier, F., Day, K.R., Battisti, A., GréGoire, J., Evans H.F. (eds). Bark and wood boring insects in living trees in Europe, a synthesis. Dordrecht: Springer, 2007, p. 63-88. Steininger, M.S., Hulcr, J., Šigut, M., Lucky, A., 2015. Simple and efficient trap for bark and ambrosia beetles (Coleoptera: Curculionidae) to facilitate invasive species monitoring and citizen involvement. Journal of Economic Entomology, 108 (3): 1115-1123. https://doi.org/10.1093/ jee/tov014

ŠŤastný, P., Bochníček, O., FAŠKo, P., Nejedlík, P., SNOPKOvá, Z., 2015. Klimatický atlas Slovenska. Climate atlas of Slovakia. Bratislava: Slovenský hydrometeorologický ústav. $132 \mathrm{p}$.

TurŇa, M., FašKo, P., IvaŇÁková, G., ŠŤastný, P., 2017. Zhodnotenie mesiaca január 2017 [Evaluation of the month January 2017]. Aktuality SHMÚ, 1. 2. 2017. [cit. 2020-6-15]. http://www.shmu.sk/sk/?page=2049\&id=805

Ungerer, M.J., Ayres, M.P., Lombardero, M.J., 1999. Climate and the northern distribution limits of Dendroctonus frontalis Zimmermann (Coleoptera: Scolytidae). Journal of Biogeography, 26 (6): 1133-1145. [cit. 2021-03-26]. http://www.jstor.org/stable/2656057

VAN Der Krieke, L., BlaAuw, F.J., Emerencia, A.C., Schenk, H.M., Slaets, J.P.J., Bos, E.H., De Jonge, P., JERONIMUS, B.F., 2017. Temporal dynamics of health and well-being: A crowdsourcing approach to momentary assessments and automated generation of personalized feedback. Psychosomatic Medicine, 79 (2): 213-223. DOI: 10.1097/PSY.0000000000000378 
Vermunt, B., Cuddington, K., Sobek-Swant, S., Crosthwaite, J.C., Lyons, D.B., Sinclair, B.J., 2012. Temperatures experienced by wood-boring beetles in the under-bark microclimate. Forest Ecology and Management, 269: 149-157. https://doi.org/10.1016/j. foreco.2011.12.019

Watanabe, K., Murakami, M., Hirao, T., Kamata, N., 2014. Species diversity estimation of ambrosia and bark beetles in temperate mixed forests in Japan based on host phylogeny and specificity. Ecological Research, 29 (2): 299-307. DOI: 10.1007/s11284-013-1123-0

Weber, B.C., McPherson, J.E., 1983. Life history of the ambrosia beetle Xylosandrus germanus (Coleoptera: Scolytidae). Annals of the Entomological Society of
America, 76 (3): 455-462. https://doi.org/10.1093/ aesa/76.3.455

Wichmann, H.E., 1955. Zur derzeitigen Verbreitung des Japanisches Nutzholzborkenkäfers Xylosandrus germanus Blandf. im Bundesgebiete [On the current distribution of the Japanese timber bark beetle Xylosandrus germanus Blandf. in federal territories]. Zeitschrift für Angewandte Entomologie, 37: 250-258. https://doi.org/10.1111/j.1439-0418.1955.tb00786.x

ZaCh, P., TopP, W., Kulfan, J., Simon, M., 2001. Colonization of two alien ambrosia beetles (Coleoptera, Scolytidae) on debarked spruce logs. Biologia, 56: 175-181.

Received May 26, 2021

Accepted August 2, 2021 